\title{
PHYSICAL QUALITY OF A YELLOW LATOSSOL UNDER INTEGRATED CROP-LIVESTOCK SYSTEM ${ }^{(1)}$
}

\author{
Fernando Silva Araújo ${ }^{(2)}$, Adeodato Ari Cavalcante Salviano ${ }^{(3)}$, Luiz \\ Fernando Carvalho Leite ${ }^{(4)}$, Zigomar Menezes de Souza ${ }^{(5)} \&$ Allan \\ Charlles Mendes de Sousa ${ }^{(6)}$
}

\begin{abstract}
SUMMARY
Soil physical quality is essential to global sustainability of agroecosystems, once it is related to processes that are essential to agricultural crop development. This study aimed to evaluate physical attributes of a Yellow Latossol under different management systems in the savanna area in the state of Piaui. This study was developed in Uruçuí southwest of the state of Piauí. Three systems of soil management were studied: an area under conventional tillage (CT) with disk plowi and heavy harrow and soybean crop; an area under no-tillage with soybean-maize rotation and millet as cover crop (NT + M); two areas under Integrated CropLivestock System, with five-month pasture grazing and soybean cultivation and then continuous pasture grazing (ICL $+S$ and ICL $+P$, respectively). Also, an area under Native Forest (NF) was studied. The soil depths studied were 0.00-0.05, $0.05-0.10$ and $0.10-0.20 \mathrm{~m}$. Soil bulk density, as well as porosity and stability of soil aggregates were analyzed as physical attributes. Anthropic action has changed the soil physical attributes, in depth, in most systems studied, in comparison to NF. In the 0.00 to $0.05 \mathrm{~m}$ depth, ICL $+\mathrm{P}$ showed higher soil bulk density value. As to macroporosity, there was no difference between the management systems studied and NF. The management systems studied changed the soil structure, having, as a result, a small proportion of soil in great aggregate classes (MWD). Converting native forest into agricultural production systems changes the soil physical quality. The Integrated Crop-Livestock System did not promote the improvement in soil physical quality.
\end{abstract}

Index terms: no-tillage system, soil compaction, animal trampling, pasture grazing.

\footnotetext{
(1) Received for publication in October 2009 and approved in March 2010.

(2) M. Sc. in Agronomy, Doctorate by the University of Campinas - UNICAMP. E-mail: fernandophb@oi.com.br

(3) Professor Dr. at Federal University of Piauí - UFPI. E-mail: adeodatosalviano@hotmail.com

(4) Researcher Dr. at EMBRAPA MEIO-NORTE, Teresina (PI). E-mail: luizf@cpamn.embrapa.br

(5) Professor Dr. at the University of Campinas - UNICAMP). E-mail: zigomarms@arg.unicamp.br

(6) Graduated in Agronomy Engineering by Federal University of Piauí - UFPI). Scholarship/CNPq. E-mail: allancharlles$2 @$ hotmail.com
} 


\title{
RESUMO: QUALIDADE FÍSICA DE UM LATOSSOLO AMARELO SOB SISTEMA DE INTEGRAÇÃO LAVOURA-PECUÁRIA NO CERRADO PIAUIENSE
}

\begin{abstract}
A qualidade física do solo é fundamental para a sustentabilidade global dos agroecossistemas, pois está relacionada com processos fundamentais para o desenvolvimento das culturas agrícolas. Este estudo teve por objetivo avaliar os atributos físicos de um Latossolo Amarelo sob diferentes sistemas de manejo no Cerrado piauiense. O trabalho foi desenvolvido no município de Uruçuí, no sudoeste do Estado do Piauí. O solo da área foi classificado como Latossolo Amarelo distrófico textura areia franca. Foram estudados três sistemas de manejo do solo: Preparo convencional (PC) com uso de aração e gradagem e monocultivo de soja; sistema de plantio direto, com milheto como cultura de cobertura $(S P D+M)$; e sistema de integração lavoura-pecuária, com pastejo de cinco meses e cultivo de soja e com pastejo contínuo $(S I L P+S$ e SILP + P). Estudou-se, ainda, uma área sob Floresta Nativa de Cerrado (FN). As profundidades estudadas foram: 0,00-0,05, 0,05-0,10 e 0,10-0,20 m. Os atributos físicos do solo avaliados foram a densidade do solo, a porosidade e a estabilidade de agregados do solo. A ação antrópica modificou os atributos físicos do solo, em profundidade, na maioria dos sistemas estudados, em comparação a FN. Na camada de 0,00 a 0,05 m, o SILP + Papresentou o maior valor de densidade do solo. Quanto à macroporosidade, não houve diferença entre os sistemas de manejo e à FN. Os sistemas de manejo estudados modificaram a estrutura do solo, resultando em menor proporção de solo nas maiores classes de agregados (DMP). A conversão da floresta nativa de Cerrado em sistemas agrícolas de produção altera a qualidade física do solo. O sistema de integração lavoura-pecuária não promoveu a melhoria da qualidade física do solo.
\end{abstract}

Termos de indexação: plantio direto, compactação do solo, pisoteio animal, pastagem.

\section{INTRODUCTION}

Sustainable use of natural resources, especially soil and water, has been growing as a relevant topic, mainly due to the increase in anthropic activities, considering that maintaining the quality of these resources is essential for the growth and development of plants and sustainability of agricultural systems. Soil productivity does not depend upon enough nutrients only, but also upon an adequate porosity system in depths where roots are grown (Souto, 2006), showing how important it is to monitor the soil physical quality for the global sustainability of agroecosystems.

Converting native areas into intensive soil management systems, through of agricultural and cattle raising activities, may change both physical attributes and soil quality, thus jeopardizing its sustainability. Physical attributes are changed by the pressure exerted on the soil surface, either by farm machines or by animal trampling. Soil compaction can be caused by rain drop impact, by excessive use of farm machinery and agricultural implements as well as by animal trampling. These are some of the main reasons why the productive capacity of agricultural soils has degraded (Albuquerque et al. 2001; Lanzanova et al. 2007). Evaluation of the consequences of these changes is grounded in the measurement of some soil physical attributes, such as soil density, soil porosity (Lanzanova et al., 2007) and soil aggregate stability (Colonego \& Rosolem, 2008).

An Integrated Crop-Livestock System (ICL) can be defined as a production system that integrates both agricultural and cattle-raising activities with temporary change or grain rotation crops and fattening livestock with grass and/or vegetables (Nicoloso et al., 2006). In ICL, changes in physical attributes can occur, more or less intensely, due to animal trampling that depends upon the intensity and frequency of pasture, since the animals apply pressure on the soil that may be higher to those applied by farm machines (Luz \& Herling, 2004). The great magnitude of these changes is connected to the management that is applied to areas under pasture grazing, which may vary according to texture, organic matter content (Defossez \& Richard, 2002), soil water content (Defossez \& Richard, 2002), crop biomass on soil (Silva et al., 2003), species of plants, pasture intensity and pasture grazing time and also animal species and category (Salton et al., 2002).

In Brazil, and especially in the Mid-North region, studies to determine the impact of the ICL on soil quality in the savannah biome are scarce. For this reason, the purpose of this work was to evaluate the Yellow Latosol physical attributes under different system managements in a savanna area in the state of Piauí. 


\section{MATERIAL AND METHODS}

The study was conducted at an area that belongs to Fazenda Nova Zelândia (New Zealand Farm) located in Uruçuí ( $3^{\circ} 37^{\prime} \mathrm{S}$ and $43^{\circ} 22^{\prime} \mathrm{W}$ ), in the southwest of the state of Piauí. The soil of the area was classified as a dystrophic Yellow Latosol, having a sandy loam texture (Jacomine et al., 1986). According to the Köppen system, the climate type is Aw, average temperature is $26.5^{\circ} \mathrm{C}$, annual rainfall is $1,200 \mathrm{~mm}$, and the rainy season is from October to April, having the rainiest quarter of the year between January and March.

Three systems of soil management were studied: an area under conventional tillage (CT) with plow disks and heavy harrow and soybean crop; an area under no-tillage with soybean-maize rotation and millet as cover crop (NT $+\mathrm{M})$; two areas under Integrated Crop-Livestock System, with five-month pasture grazing and soybean cultivation and then continuous pasture grazing (ICL $+\mathrm{S}$ and ICL $+\mathrm{P}$, respectively). In areas under an Integrated CropLivestock System, after soybean cultivation, a rotation with corn cultivation and brachiaria as cover crop was made, and animal pasture was managed at a rate of 2.4 A.U. ${ }^{(7)}$ per hectare. The grazing of animals in the area took place 45 days after the crop corn harvesting. Under ICL $+\mathrm{S}$ an effective permanence of animals was 42 days, while under ICL $+\mathrm{P}$ an effective permanence of animals reached 168 days. Brachiária production was of $42 \mathrm{t} \mathrm{ha}^{-1}$ green mass. As a natural soil condition, an area under Native Forest (NF) was evaluated as well (Table 1).

Soil sampling was performed during the agricultural year of 2007/2008. In each system, four mini-trenches were randomly opened, $0.50 \mathrm{~m}$ deep, $0.40 \mathrm{~m}$ wide and $0.60 \mathrm{~m}$ long, and each one of them was a repetition. The studied soil depths were 0.00 $0.05,0.05-0.10$ and $0.10-0.20 \mathrm{~m}$.

Table 1. History of different management systems
Soil bulk density and porosity as well as stability of soil aggregates were analyzed as soil physical attributes. In order to evaluate soil density and porosity, undeformed soil samples were collected through volumetric rings, with 0.04 high and $0.05 \mathrm{~mm}$ of diameter as average dimensions.

A tension table was used to determine soil porosity (macroporosity and microporosity). After saturation, samples were submitted to a tension of $0.006 \mathrm{MPa}$ (Embrapa, 1997). Total porosity and soil bulk density were obtained according to Embrapa (1997) and macroporosity by the difference between total porosity and microporosity.

Soil samples to determine the aggregate stability were collected and stored so that the aggregates would not undergo any deformation. The material that went through a sieve with meshes of $4.76 \mathrm{~mm}$ and retained on a sieve with meshes of $2.00 \mathrm{~mm}$ was used to study aggregate stability. Through a method based on Yoder (1936), the aggregate stability was obtained by the slightly wet tamis procedure, after being slowly wetted by capillary action (Castro Filho et al., 1998). A set of sieves with meshes of $2.00 ; 1.00 ; 0.50,0.25$ and $0.105 \mathrm{~mm}$ was used and taken to a vertical oscillation device, graded to an extent of $0.04 \mathrm{~m}$ high and a frequency of 32 oscillations per minute and submitted to a sieve process for $10 \mathrm{~min}$ (Embrapa, 1997).

The retained soil was quantified in each sieve, obtaining five classes of distinct aggregate diameters $(4.76-2.00 ; 2.00-1.00 ; 1.00-0.50 ; 0.50-0.25$ and $0.105 \mathrm{~mm}$ ). From these mass values and knowing the water content of soil samples submitted to the tamis process, both mean weight diameter (MWD) and geometric mean diameter (GMD) were calculated in line with Kemper \& Rosenau (1986) using the equations 1 and 2 .

$$
\boldsymbol{M W D}=\sum_{i=1}^{n} x_{i} w_{i}
$$

with wi = the weight of each class in the total value; $\mathrm{xi}=$ mean diameter classes $(\mathrm{mm})$.

\begin{tabular}{|c|c|c|c|c|c|c|}
\hline \multirow{2}{*}{ System } & \multicolumn{6}{|c|}{ History of agricultural years } \\
\hline & $2001 / 2002$ & $2002 / 2003$ & $2003 / 2004$ & $2004 / 2005$ & $2005 / 2006$ & $2006 / 2007$ \\
\hline $\mathrm{ICL}+\mathrm{S}$ & Rice & Soybean & Corn+Cattle & Soybean /Millet & Soybean /Millet & Soybean/Millet \\
\hline $\mathrm{ICL}+\mathrm{P}$ & Rice & Soybean & Corn+Cattle & Brachiaria/Cattle & Brachiaria/Cattle & Brachiaria/Cattle \\
\hline $\mathrm{NT}+\mathrm{M}$ & Native forest & Native forest & Soybean/Millet & Soybean/Millet & Soybean/Millet & Soybean/Millet \\
\hline $\mathrm{CT}$ & Native forest & Native forest & Native forest & Native forest & Soybean & Soybean \\
\hline NF & Native forest & Native forest & Native forest & Native forest & Native forest & Native forest \\
\hline
\end{tabular}

NF: Native Forest; CT: Conventional Tillage; ICL + P: Integrated Crop-Livestock with continuous pasture grazing; ICL + S: Integrated Crop-Livestock with soybean; NT + M: No-tillage System with covering culture millet.

(7) A.U.: Animal Unit weighing $450 \mathrm{~kg}$. 


$$
\boldsymbol{G M D}=\exp \left[\frac{\sum_{i=1}^{n} w_{i} \log x_{i}}{\sum_{i=1}^{n} x_{i}}\right]
$$

with wi $=$ weight of aggregates (g) within a class of aggregates with an average diameter of $\mathrm{xi} ; \mathrm{xi}=$ mean diameter classes $(\mathrm{mm})$.

The obtained results were observed under the analysis of variance and the comparison of means by the Tukey test $(p<0.05)$ was carried out, when it was necessary, using the SAEG software, version 9.0.

\section{RESULTS AND DISCUSSION}

Anthropic action has significantly affected $(p<0.05)$ soil bulk density, leading to an increase in depth, in most studied systems, when it is compared to a native forest (NF) (Table 2). This behavior probably results from farm machine traffic in this area as well as from an effect of animal trampling that exerts pressure on the soil and thus dislocates soil particles to the inner porous place, which leads to a reduction in macroporosity and consequently in soil compaction. Spera et al. (2004) observed similar results when working with grain production cultures and pasture grazing compared to native vegetation of subtropical forests.

In the 0.00-0.05 m depth, the Integrated CropLivestock System with continuous pasture grazing $(\mathrm{ICL}+\mathrm{P})$ showed the greatest soil bulk density value, which indicates the effect of superficial soil compaction that can occur in integrated crop-livestock systems under no-tillage, due to animal trampling pressure on the soil surface and no-tillage procedures (Marchão et al., 2007; Lanzanova et al., 2007). These results are similar to those reported by Spera et al. (2004), Marchão et al. (2007) and Flores et al. (2007).

Integrated Crop-Livestock with soybean (ICL + S), ICL + P and conventional tillage (CT), in the depth 0.05 to $0.10 \mathrm{~m}$ provided greater pressure on soil particles, resulting in the highest values of soil density. On the other hand, in the 0.10 to $0.20 \mathrm{~m}$ depths, CT showed higher density $\left(1.5 \mathrm{Mg} \mathrm{m}^{-3}\right)$ as opposed to NF only, with no differences to other systems. A greater density value in a CT system can be associated with the accumulation of farm machine traffic pressure as well as with the depth in soilworking implements used to prepare the soil for the referred managing system. Flores et al. (2007), working with different pressures of grazing at a Red Latosol, stated that the subsurface compaction is more related to the total power applied by axles of farm machines, regardless of the pressure exerted on the surface, which is in agreement with results showed in this study.

There were differences in microporosity $(p<0.05)$ in depth 0.00-0.05 m only (Table 2). ICL + P, NT + M and $\mathrm{CT}$ were the same and showed an intermediate behavior as to NF and ICL + P.

For macroporosity, there was no significant difference $(p<0.05)$ between the management system and NF. However, Spera et al. (2004) and Marchao et al (2007) observed a reduction in macroporosity and total porosity in the management systems compared to the native forest, which indicates that, although no differences have been observed in this study, macroporosity can be considered one of the main attributes affected by crop systems or pasture grazing, mainly on surface horizons, as reported by Balbino et al. (2003).

NF showed the highest values $(\mathrm{p}<0.05)$ of mean weight diameter (MWD) in all depths evaluated

Table 2. Soil density, macroporosity and microporosity of Yellow Latosol at depths 0.00-0.05, 0.05-0.10 and $0.10-0.20 \mathrm{~m}$ under different management systems ${ }^{(1)}$

\begin{tabular}{|c|c|c|c|c|c|c|}
\hline Physical attribute & Soil densi & & Microporc & sity & & Macroporosity \\
\hline Soil depth & $0.00-0.05 \quad 0.05-0.10$ & $0.10-0.20 \mathrm{~m}$ & $0.00-0.050 .05-0.10$ & $0.10-0.20 \mathrm{~m}$ & $0.00-0.05$ & $0.05-0.10 \quad 0.10-0.20 \mathrm{~m}$ \\
\hline
\end{tabular}

\begin{tabular}{|c|c|c|c|c|c|c|c|c|c|}
\hline \multirow{2}{*}{$\begin{array}{c}\text { Management system } \\
\text { ICL + S }\end{array}$} & \multicolumn{3}{|c|}{$\mathrm{Mg} \mathrm{m}^{-3}$} & \multicolumn{5}{|c|}{$\mathrm{m}^{3} \mathrm{~m}^{-3}$} & \multirow[b]{2}{*}{$0.072 \mathrm{~b}$} \\
\hline & $1.32 \mathrm{~b}$ & $1.43 \mathrm{a}$ & $1.44 \mathrm{ab}$ & $0.447 \mathrm{ab}$ & $0.434 \mathrm{~ns}$ & $0.423 \mathrm{~ns}$ & $0.067 \mathrm{~ns}$ & $0.071 \mathrm{~ns}$ & \\
\hline $\mathrm{ICL}+\mathrm{P}$ & $1.48 \mathrm{a}$ & $1.36 \mathrm{ab}$ & $1.41 \mathrm{ab}$ & $0.442 \mathrm{~b}$ & $0.449 \mathrm{~ns}$ & $0.441 \mathrm{~ns}$ & $0.049 \mathrm{~ns}$ & $0.064 \mathrm{~ns}$ & $0.060 \mathrm{ab}$ \\
\hline $\mathrm{NT}+\mathrm{M}$ & $1.26 \mathrm{~b}$ & $1.28 \mathrm{ab}$ & $1.42 \mathrm{ab}$ & $0.453 \mathrm{ab}$ & $0.441 \mathrm{~ns}$ & $0.423 \mathrm{~ns}$ & $0.065 \mathrm{~ns}$ & $0.066 \mathrm{~ns}$ & $0.067 \mathrm{ab}$ \\
\hline $\mathrm{CT}$ & $1.33 \mathrm{~b}$ & $1.34 \mathrm{ab}$ & $1.55 \mathrm{a}$ & $0.453 \mathrm{ab}$ & $0.459 \mathrm{~ns}$ & $0.473 \mathrm{~ns}$ & $0.075 \mathrm{~ns}$ & $0.065 \mathrm{~ns}$ & $0.075 \mathrm{ab}$ \\
\hline $\mathrm{NF}$ & $1.27 \mathrm{~b}$ & $1.30 \mathrm{~b}$ & $1.34 \mathrm{~b}$ & $0.489 \mathrm{a}$ & $0.453 \mathrm{~ns}$ & $0.467 \mathrm{~ns}$ & $0.082 \mathrm{~ns}$ & $0.098 \mathrm{~ns}$ & $0.110 \mathrm{a}$ \\
\hline $\mathrm{CV}(\%)$ & 5.11 & 3.62 & 5.99 & 4.45 & 7.35 & 6.33 & 28.4 & 33.29 & 37.41 \\
\hline
\end{tabular}

(1) ICL + S: Integrated Crop-Livestock with soybean; ICL + P: Integrated Crop-Livestock with continuous pasture grazing; NT + M: No-tillage System with covering culture millet; CT: Conventional Tillage; NF: Savanna-like Native Forest. ${ }^{(2)}$ Means followed by the same letter, in columns, in each soil depth, do not differ among each other by Tukey test at $5 \%$. Ns: not significant. 
reflecting its balance state and favoring the aggregate maintenance and stability, as well as greater root density showed by grass perennials in this area, comprehending a larger volume of soil (Table 3).

The MWD values, in depths $0.00-0.05$ and $0.05-$ $0.10 \mathrm{~m}$, were the same between ICL + P and ICL $+\mathrm{S}$, differing significantly $(p<0.05)$ in depth $0.10-0.20 \mathrm{~m}$, where ICL + P showed higher MWD values. When compared to ICL $+\mathrm{S}$, more stability in areas that were submitted to continuous pasture grazing was demonstrated than when compared to areas that went through changes between pasture grazing and grain cultivation. This effect is probably due to the fact that grass has a divided root system that allows greater aggregation because it has more contact with soil particles. Similar results were observed by Souza et al. (2008).

The CT showed MWD similar values to $(\mathrm{p}>0.05)$ native forests in the $0.00-0.05$ and $0.10-0.20 \mathrm{~m}$ depths (Table 3). This can probably be attributed to the soil texture studied and to not much time of CT appropriation in this area (Table 1). Castro Filho et al. (1998) reported different results while studying aggregate stability in a Red Latosol under different soil management systems. They state that CT leads to a rupture of aggregates stimulated by intense tillage of soil thus jeopardizing the aggregate stability and the reduction in MWD during the following cultivations that adopted this system. The little variation observed among MWD values as well as among management systems and depths evaluated could be motivated by the method used, which as Silva $\&$ Mielniczuk (1997) stated does not differ the new aggregate that were just formed from those that, not only were formed, but also have gone through a stability process. For this reason, in conventional tillage, aggregation could have been induced by the compacting action of soil particles; however, without the occurrence of mechanisms that contribute to its stability (Cruz et al., 2003).

Under NT + M, MWD values were lower in $\mathrm{NT}+\mathrm{M}$ than those verified in NF areas, except for the depth $0.10-0.20 \mathrm{~m}$, because it did not show significant differences. Marcolan et al. (2007) while studying an Acrisol with loam sandy-clay texture stated that the soil tillage to incorporate lime carried out in the first year of NT adoption produced negative effects on aggregates, especially on greater and more stable ones formed throughout time. The reason why a no-tillage system still did not provide positive reflections on the structural stability of this soil with sandy characteristics is due to the fact that it was established four years ago. This is in agreement with Assis \& Lanças (2005) who verified that a no-tillage system with 1,4 , and 5 years of implementation showed organic matter and soil physical attribute values similar to a conventional tillage system and, only the treatment after a 12 year period of no-tillage, showed greater values, getting close to native forest.

Table 3. Mean Weight Diameter (MWD) and Geometric Mean Diameter (GMD) of Yellow Latosol at depths $0.00-0.05,0.05-0.10$ and $0.10-0.20 \mathrm{~m}$ under different management systems ${ }^{(1)}$

\begin{tabular}{|c|c|c|c|c|c|c|c|}
\hline \multirow{2}{*}{$\begin{array}{c}\text { Management } \\
\text { system }\end{array}$} & \multicolumn{5}{|c|}{$\%$ of Aggregate class - Mean in millimeters per class } & \multirow{2}{*}{ MWD } & \multirow{2}{*}{ GMD } \\
\hline & $4.76-2.0$ & $2.0-1.0$ & $1.0-0.50$ & $0.5-0.25$ & 0.105 & & \\
\hline & & & & & & & 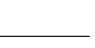 \\
\hline & \multicolumn{5}{|c|}{0.00 to $0.05 \mathrm{~m}$} & & \\
\hline $\mathrm{ICL}+\mathrm{S}$ & 66.96 & 4.72 & 5.84 & 13.60 & 5.28 & $2.41 \mathrm{~b}$ & $1.31 \mathrm{~b}$ \\
\hline $\mathrm{ICL}+\mathrm{P}$ & 76.58 & 3.06 & 1.83 & 8.27 & 5.32 & $2.70 \mathrm{ab}$ & $1.42 \mathrm{ab}$ \\
\hline $\mathrm{NT}+\mathrm{M}$ & 71.84 & 5.08 & 3.24 & 8.66 & 6.78 & $2.60 \mathrm{~b}$ & $1.37 \mathrm{~b}$ \\
\hline $\mathrm{CT}$ & 81.29 & 1.94 & 2.37 & 6.83 & 3.49 & $2.83 \mathrm{ab}$ & $1.48 \mathrm{ab}$ \\
\hline NF & 89.34 & 1.50 & 1.27 & 2.49 & 1.82 & $3.09 \mathrm{a}$ & $1.59 \mathrm{a}$ \\
\hline $\mathrm{CV}(\%)$ & \multicolumn{5}{|c|}{0.05 to $0.10 \mathrm{~m}$} & 7.8 & 6.19 \\
\hline $\mathrm{ICL}+\mathrm{S}$ & 65.84 & 5.43 & 5.76 & 15.55 & 5.36 & $2.54 \mathrm{ab}$ & $1.29 \mathrm{~b}$ \\
\hline $\mathrm{ICL}+\mathrm{P}$ & 75.21 & 5.84 & 2.94 & 8.28 & 4.50 & $2.67 \mathrm{ab}$ & $1.42 \mathrm{ab}$ \\
\hline $\mathrm{NT}+\mathrm{M}$ & 63.59 & 4.36 & 3.79 & 13.74 & 8.48 & $2.30 \mathrm{~b}$ & $1.39 \mathrm{ab}$ \\
\hline $\mathrm{CT}$ & 67.60 & 3.38 & 4.63 & 14.00 & 5.43 & $2.45 \mathrm{ab}$ & $1.32 \mathrm{ab}$ \\
\hline \multirow{2}{*}{$\begin{array}{l}\mathrm{NF} \\
\mathrm{CV}(\%)\end{array}$} & 92.81 & 2.03 & 1.61 & 1.59 & 0.70 & $3.18 \mathrm{a}$ & $1.63 \mathrm{a}$ \\
\hline & \multicolumn{5}{|c|}{0.10 to $0.20 \mathrm{~m}$} & 14.17 & 7.78 \\
\hline $\mathrm{ICL}+\mathrm{S}$ & 37.63 & 11.50 & 13.24 & 21.85 & 9.98 & $1.67 \mathrm{~b}$ & $1.16 \mathrm{c}$ \\
\hline $\mathrm{ICL}+\mathrm{P}$ & 74.24 & 4.69 & 3.42 & 10.74 & 4.01 & $2.65 \mathrm{a}$ & $1.40 \mathrm{ab}$ \\
\hline $\mathrm{NT}+\mathrm{M}$ & 65.90 & 5.34 & 5.99 & 13.18 & 7.91 & $2.42 \mathrm{a}$ & $1.27 \mathrm{bc}$ \\
\hline CT & 66.02 & 4.00 & 5.74 & 12.12 & 6.15 & $2.39 \mathrm{ab}$ & $1.31 \mathrm{bc}$ \\
\hline $\mathrm{NF}$ & 88.87 & 2.33 & 2.02 & 2.51 & 1.26 & $3.07 \mathrm{a}$ & $1.59 \mathrm{a}$ \\
\hline CV (\%) & & & & & & 14.17 & 7.95 \\
\hline
\end{tabular}

(1) ICL + S: Integrated Crop-Livestock with soybean; ICL + P: Integrated Crop-Livestock with continuous pasture grazing; NT + M: No-tillage System with covering culture millet; CT: Conventional Tillage; NF: Native Forest. ${ }^{(2)}$ Means followed by the same letter in columns in each soil depth do not differ among each other by Tukey test at $5 \%$. 
Soil MWD under NF showed higher values than those observed in management systems, in all threestudied depths (Table 3). This can imply the effect of the dense root system of grass that constitutes the native vegetation in soil aggregate stability to the detriment of farm machine traffic as well as cattle tramping originated from soil management systems. Soil under native forest conditions in general, has shown a better structure connected to the highest contents of organic matter, probably resulting from a group of factors that consider some difference in quantity and quality of organic matter incorporated into the soil, as well as existing phyto-climatic conditions, which favor the vegetation development, as reported by some studies (Longo et al., 1999).

The ICL + P soil profile showed a tendency to better MWD values compared to ICL $+\mathrm{S}$ indicating a significant difference $(p<0.05)$ in the 0.10 to $0.20 \mathrm{~m}$ depths. This greater action on the subsurface showed by ICL $+\mathrm{S}$ as opposed to ICL $+\mathrm{P}$ has the same observed tendency when compared to MWD. Greater soil aggregation meets the requirement of conservationist soil management, once the greater aggregates contribute to their better resistance against the erosion process (Carvalho Filho et al., 2007).

\section{CONCLUSIONS}

1. Converting native forest to agricultural systems of production changes the soil physical quality.

2 . The management systems studied changed soil structure, resulting in a small proportion of soil in greater aggregate classes (MWD).

3. The Integrated Crop-Livestock System did not promote improvement in soil physical quality.

\section{LITERATURE CITED}

ALBUQUERQUE, J.A.; SANGOI, L. \& ENDER, M. Efeitos da integração lavoura-pecuária nas propriedades físicas do solo e características da cultura do milho. R. Bras. Ci. Solo, 25:717-723, 2001.

ASSIS, R.L. \& LANÇAS, K.P. Avaliação dos atributos físicos de um Nitossolo Vermelho distroférrico sob sistema plantio direto, preparo convencional e mata nativa. R. Bras. Ci. Solo, 29:515-522, 2005.

BALBINO, L.C.; BROSSARD, M.; STONE, L.F.; BRUAND, A. \& LEPRUN, J.C. Estrutura e propriedades hidráulicas em Latossolos sob cultivo na região do cerrado. Santo Antônio de Goiás, Embrapa Arroz e Feijão, 2003. 43p.

CARVALHO FILHO, A.; SILVA, R.P.; CENTURION, J.F.; CARVALHO, L.C.C. \& LOPES, A. Agregação de um Latossolo Vermelho submetido a cinco sistemas de preparo do solo. Eng. Agríc., 27:317-325, 2007.
CASTRO FILHO, C.; MUZILLI, O. \& PODANNOSCHI, A.L. Estabilidade de agregados e sua relação com o teor de carbono orgânico num Latossolo Roxo distrófico, em função de sistemas de plantio, rotação de culturas e métodos de preparo das amostras. R. Bras. Ci. Solo, 22:527538, 1998.

COLONEGO, J.C. \& ROSOlEM, C.A. Estabilidade de agregados do solo após manejo com rotações de culturas e escarificação. R. Bras. Ci. Solo, 32:1399-1407, 2008.

CRUZ, A.C.R.; PAULETTO, E.A.; FLORES, C.A. \& SILVA, J.B. Atributos físicos e carbono orgânico de um Argissolo Vermelho sob diferentes sistemas de manejo. R. Bras. Ci. Solo, 27:1105-1112, 2003.

DEFOSSEZ, P. \& RICHARD, G. Models of soil compaction due to traffic and their evaluation. Soil Tillage Res., 67:41-64, 2002.

EMPRESA BRASILEIRA DE PESQUISA AGROPECUÁRIA EMBRAPA. Centro Nacional de Pesquisa de Solos. Manual de métodos de análise de solo. 2.ed. Rio de Janeiro, 1997. 212p.

FLORES, J.P.C.; ANGHINONI, I.; CASSOL, L.C.; CARVALHO, P.C.F.; LEITE, J.G.; DAL, B. \& FRAGA, T.I. Atributos físicos do solo e rendimento de soja em sistema plantio direto em integração lavoura pecuária com diferentes pressões de pastejo. R. Bras. Ci. Solo, 31:771-780, 2007.

JACOMINE, P.K.T.; CAVALCANTI, A.C.; PESSOA, S.C.P.; BURGOS, N.; MELO FILHO, H.F.R.; LOPES, O.F. \& MEDEIROS, L.A.R. Levantamento exploratórioreconhecimento de solos do Estado do Piauí. Rio de Janeiro, Embrapa - SNLCS/ Sudene - DRN, 1986. 782p.

KEMPER, W.D. \& ROSENAU, R.C. Aggregate stability and size distribution. In: KLUTE, A., ed. Methods of soil analysis. Physical and inerological methods. Madison, Soil Science Society of America, 1986. Part I. p.425-442. (Agronomy Monograph, 9).

LANZANOVA, M.E.; NICOLOSO, R.S.; LOVATO, T.; ELTZ, F.L.F.; AMADO, T.J.C. \& REINERT, D.J. Atributos físicos do solo em sistema de integração lavoura-pecuária sob plantio direto. R. Bras. Ci. Solo, 31:1131-1140, 2007.

LONGO, R.M.; ESPÍNDOLA, C.R. \& RIBEIRO, A.I. Modificações na estabilidade de agregados no solo decorrentes da introdução de pastagens em áreas de cerrado e floresta amazônica. R. Bras. Eng. Agríc. Amb., 3:276-280, 1999.

LUZ, P.H.C. \& HERLING, V.R. Impactos do pastejo sobre as propriedades físicas do solo. In: SIMPÓSIO SOBRE MANEJO ESTRATÉGICO DA PASTAGEM, 2., Viçosa, MG, 2004. Anais... Viçosa, MG, Universidade Federal de Viçosa, 2004. p.209-250.

MARCOLAN, A.L.; ANGHINONI, I.; FRAGA, T.I. \& LEITE, J.G.D.B. Recuperação de atributos físicos de um Argissolo em função do seu revolvimento e do tempo de semeadura direta. R. Bras. Ci. Solo, 31:571-579, 2007.

MARCHÃO, R.L.; BALBINO, L.C.; SILVA, E.M.; SANTOS JUNIOR, J.D.G.; SÁ, M. A.C.; VILELA, L. \& BECQUER, T. Qualidade física de um Latossolo Vermelho sob sistemas de integração lavoura-pecuária no Cerrado. Pesq. Agropec. Bras., 42:873-882, 2007. 
NICOLOSO, R.S.; LANZANOVA, M.E. \& LOVATO, T. Manejo das pastagens de inverno e potencial produtivo de sistemas de integração lavoura-pecuária no estado do Rio Grande Do Sul. Ci. Rural, 36:1799-1805, 2006.

SALTON, J.C.; FABRÍCIO, A.C.; MACHADO, A.Z.M. \& OLIVEIRA, H. Pastoreio de aveia e compactação do solo. R. Plantio Direto, 69:32-34, 2002.

SILVA, I.F. \& MIELNICZUK, J. Ação do sistema radicular de plantas na formação e estabilização de agregados do solo. R. Bras. Ci. Solo, 20:113-117, 1997.

SILVA, A.P.; INHOFF, S. \& CORSI, M. Evaluation of soil compaction in an irrigated short-duration grazing system. Soil Tillage Res., 70:83-90, 2003.
SOUTO, M.S. Pastagem de aveia e azevém na integração lavoura-pecuária: Produção de leite e características do solo. Curitiba, Universidade Federal do Paraná, 2006. 80p. (Tese de Mestrado)

SOUZA, E.; CARNEIRO, M. \& BANYS, V. Fitomassa e acúmulo de nitrogênio, em espécies vegetais de cobertura do solo para um Latossolo Vermelho distroférrico de Cerrado. Acta Sci. Agron., 30:519-523, 2008.

SPERA, S.T.; SANTOS, H.P.; FONTANELLI, R.S. \& TOMM, G.O. Efeitos de sistemas de produção de grãos envolvendo pastagens sob plantio direto nos atributos físicos de solo e na produtividade. R. Bras. Ci. Solo, 28:533$542,2004$. 